\title{
Kemampuan Ekstrak dan Bakteri Inhabitan Mucuna pruriens Linn. dalam Menekan Penyakit Bercak Daun Cercospora dan Meningkatkan Pertumbuhan Tanaman Kacang Tanah
}

\author{
Endah Yulia, Fitri Widiantini, dan Ramdan Firmansah \\ Jurusan Hama dan Penyakit Tumbuhan, Fakultas \\ Pertanian Universitas Padjadjaran, Kampus Jatinangor, \\ Bandung 40600
}

\author{
Agung Karuniawan \\ Jurusan Budidaya Pertanian, Fakultas Pertanian, \\ Universitas Padjadjaran, Kampus Jatinangor, \\ Bandung 40600
}

\begin{abstract}
Effectiveness of extract and inhabitant bacteria of Mucuna pruriens Linn. in suppressing leaf spot disease on and promoting plant growth of peanut
\end{abstract}

Velvet bean (Mucuna spp.) is potential to be developed as bio-pesticide. Chemical compound extracted from the seeds of Mucuna has been commonly used in healing of several diseases in human health. This research was aimed to reveal effectiveness of Mucuna seed and leaf extracts in suppressing cercospora leaf spot disease on peanut and inhabitant bacteria of Mucuna in promoting plant growth and suppressing cercospora leaf spot. Research method used was experimental method to test biopesticide potency of seed and leaf extract prepared from two accessions of Mucuna that were original of East Timor and West Java Provinces, and to test growth promoting and disease suppressing ability of the inhabitant bacteria from those two accessions when were applied through seed treatment on peanut seed. The research was carried out in the Phytopathology Laboratory and glass house of Department of Plant Pest Science and Disease, Faculty of Agriculture, Universitas Padjadjaran at \pm $700 \mathrm{~m}$ above see level from July until November 2007. The result demonstrated the potency of antimicrobial of Mucuna extracts with seed ethanol extract of East Timor accession was superior compared to the other extracts in inhibiting the growth of Cercospora sp.. Meanwhile, six inhabitant bacterial isolates tended to promote the peanut growth and one bacterial isolate significantly suppressed the disease with the suppression percentage of 70.85 .

Key words: Plant extract, inhabitant bacteria, M. pruriens, Cercospora sp.

\section{ABSTRAK}

Tanaman velvet bean (Mucuna spp.) merupakan tanaman yang memiliki potensi untuk dikembangkan sebagai bahan biopestisida. Senyawa kimia yang diekstrak dari biji Mucuna telah banyak digunakan dalam pengobatan beberapa penyakit dalam bidang kesehatan manusia. Penelitian ini bertujuan untuk menguji ekstrak biji dan daun Mucuna dalam menekan pertumbuhan Cercospora sp. serta menguji kemampuan bakteri inhabitan Mucuna dalam memacu pertumbuhan tanaman dan menekan perkembangan penyakit bercak daun cercospora pada tanaman kacang tanah. Metode penelitian berupa metode eksperimen untuk menguji potensi ekstrak biji dan daun Mucuna dalam menekan pertumbuhan Cercospora sp. dari dua aksesi Mucuna asal NTT dan Jabar, dan menguji kemampuan isolat bakteri yang diisolasi dari dua aksesi tersebut dalam memacu pertumbuhan tanaman dan penekanan penyakit bercak daun cercospora yang diaplikasikan melalui perlakuan benih pada benih kacang tanah. Penelitian dilaksanakan di Laboratorium Fitopatologi dan rumah 
kaca Jurusan Hama dan Penyakit Tumbuhan, Fakultas Pertanian, Universitas Padjadjaran, pada ketinggian $\pm 700 \mathrm{~m}$ dpl, dari bulan Juli sampai bulan November 2007. Hasil penelitian menunjukkan potensi antimikrobial ekstrak Mucuna and ekstrak etanol biji Mucuna asal NTT menunjukkan penekanan pertumbuhan Cercospora sp. yang lebih baik dibandingan dengan ekstrak lainnya. Sementara itu, enam isolat bakteri inhabitan Mucuna cenderung meningkatkan pertumbuhan tanaman kacang tanah dan terdapat satu isolat bakteri yang secara nyata menekan penyakit bercak daun cercospora dengan penekanan penyakit sebesar $70,85 \%$.

Kata kunci: Ekstrak tanaman, bakteri inhabitan, M. pruriens, Cercospora sp.

\section{PENDAHULUAN}

Penyakit bercak daun yang disebabkan oleh Cercospora sp. menjadi kendala utama dalam peningkatan produktivitas tanaman kacang tanah dan kehilangan hasil panen dapat mencapai $80 \%$ apabila penyakit daun ini tidak dikendalikan (Grichar et al., 1998). Di Indonesia dilaporkan intensitas serangan berkisar antara $34-38 \%$ serta dapat mengurangi jumlah polong total, jumlah polong bernas, berat biji, dan jumlah dan berat biji per tanaman, juga dilaporkan dapat mengurangi produksi tanaman sampai 50\% (Semangun, 1993). Berbagai upaya untuk mengendalikan penyakit ini telah banyak dilakukan di antaranya dengan merakit kultivar tahan (Dwivedi et al., 2002; Pensuk et al., 2003; Utomo dkk., 2005) dan pemakaian fungisida (Chandra et al., 1998).

Namun, penggunaan varietas tahan kurang dapat diandalkan karena Cercospora akan selalu beradaptasi membentuk tipe-tipe baru dengan patogenisitas yang lebih kuat (Nindiawaty dkk., 2003). Begitu juga dengan penggunaan fungisida, walaupun dikctahui fungisida benomil dan klorotalonil efektif mengendalikan bercak daun cercospora (Culbreath et al., 2002), dilaporkan juga bahwa beberapa fungisida dapat meningkatkan resiko berkembangnya ketahanan populasi jamur patogen ini (Zhang \& Reddy, 2001). Dilaporkan juga bahwa Cercospora merupakan salah satu dari beberapa jamur patogen penting yang telah diketahui memiliki ketahanan terhadap satu atau lebih fungisida sistemik (Agrios, 1997; Cu \& Phipps, 1992). Karena hai-hai di atas diperiukan upaya uniuk mencari alternatif pengendalian lain.

Mucuna pruriens merupakan tanaman legume yang populer sebagai tanaman obat-obatan. Senyawa-senyawa yang dikandungnya telah dimanfaatkan untuk mengobati berbagai penyakit. Setiap bagian dari tanaman ini mengandung senyawa penting yang dapat dimanfaatkan sebagai obat. Kandungan senyawa kimia dalam $M$. pruriens yang berupa 3-(3,4-dihydroxyphenyl)-1-alanine (LDOPA), serta senyawa-senyawa antioksidan dan antimikrobial lainnya (Rajeshwar et al., 2005) membuat tanaman ini populer sebagai tanaman obatobatan terutama dimanfaatkan dalam bidang kesehatan manusia. Hal ini dapat menunjukkan adanya potensi efikasi Mucuna terhadap semua jenis mikroorganisme. Sebelumnya dilaporkan bahwa ekstrak biji $M$. pruriens bersifat antimikrobial yang menghambat pertumbuhan bakteri gram positif maupun bakteri gram negatif (Rajeswhar et al., 2005). Morris (1999) juga melaporkan bahwa beberapa senyawa yang terkandung dalam velvet bean ini mampu berperan sebagai biopestisida.

Sementara itu, Kumar et al. (2006) melaporkan bahwa ditemukan keragaman genetik bakteri rhizobia yang mengolonisasi akar $M$. pruriens. Bakteri rhizobia adalah bakteri pemfiksasi nitrogen yang membentuk nodul pada perakaran yang juga merupakan anggota terpenting dari bakteri Plant Growth Promoting Rhizobacteria (PGPR). Bakteri PGPR telah secara intensif diteliti• sebagai agens biokontrol, selain mampu meningkatkan pertumbuhan tanaman juga mampu menekan perkembangan patogen penyebab penyakit (Benhamou et al., 2000; Kumar et al., 2006).

Meskipun sampai saat ini bakteri PGPR yang dilaporkan efektif diisolasi dari daerah perakaran, tidak tertutup kemungkinan bakteri pemacu pertumbuhan tanaman diperoleh dari bagian lain dari tanaman (secara umum disebut Plant Giowth Promoting Bactcria, PGPB). Bakteri yang mengolonisasi daerah bagian aras tanaman seperti filoplen terekspos langsung dengan lingkungan. seperti suhu tinggi dan kelembaban "yang berfluktuasi dengan ketersedian nutrisi yang terbatas, sehingga kemungkinan bakteri yang diisolasi dari daerah filoplen akan lebih mampu 
bertahan dan memperbanyak diri dibandingkan dengan bakteri di daerah yang kaya akan nutrisi seperti daerah perakaran (Kishore et al., 2005).

Selain bakteri filoplen, bakteri inhabitan Mucuna yang diisolasi dalam penelitian ini merupakan bakteri endofit yaitu bakteri yang hidup dan berkembang di dalam tanaman. Karena keberadaannya di dalam tanaman maka keunggulan bakteri ini sebagai agens biokontrol yaitu mampu mengurangi pengaruh negatif dari lingkungan. Kondisi lingkungan yang cocok bagi bakteri endofit juga sama dengan yang diperlukan oleh tanaman inangnya (Benhamou et al., 2000). Bakteri endofit dapat diisolasi dari berbagai macam jenis tanaman dan dapat ditemukan pada setiap bagian tanaman baik dari akar, batang, maupun daun (Zinniel et al., 2002).

Beberapa bakteri endofit dilaporkan menghasilkan zat antimikrob seperti antibiotik atau HCN yang berperan penting dalam mekanisme melawan patogen tanaman (Reiter et al., 2002). Bakteri rhizobia Rhizobium meliloti yang diisolasi dari perakaran $M$. pruriens selain mampu meningkatkan pertumbuhan kacang tanah juga mampu meningkatkan kemampuan tanaman untuk menghambat serangan Macrophomina phaseolina, penyebab penyakit busuk pada kacang tanah, dengan memproduksi siderofor (Arora et al, 2001).

Walaupun demikian, bakteri yang berasal dari permukaan daun (filoplen) juga memiliki keuntungan lain jika digunakan sebagai agen biokontrol. Bakteri ini seringkali memiliki ketahanan terhadap lingkungan yang ekstrim. Interaksi bakteri filoplen dengan suhu yang ekstrim, kelembaban yang berfluktuasi dan keterbatasan nutrisi, menjadikan bakteri filoplen relatif tahan terhadap pengaruh lingkungan (Kishore et al., 2005). Viera et al. (2006) melaporkan bahwa bakteri filoplen (Bacillus circus) bersifat antagonis terhadap

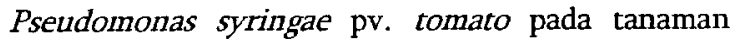
tomat serta dapat menginduksi ketahanan sistemik melalui efek antibiosis.

Potensi penggunaan bakteri yang berasosiasi dengan tanaman sebagai agen pemacu pertumbuhan tanaman sering dihubungkan sebagai PGPB dan yang telah banyak dikenal adalah PGPR (Compant et al., 2005). Compant et al. (2005) menyebutkan bahwa asosiasi beberapa PGPB dengan tanaman dapat menginduksi ketahanan sistemik melawan patogen. Laporan tentang PGPB sebagai penginduksi ketahanan sistemik sebagian besar melibatkan rizobakteria. Wei et al. (1991) dan Zhang \& Reddy
(2001) melaporkan bakteri PGPR yang dapat menginduksi ketahanan terhadap penyakit antraknos (Colletotricum orbiculae) pada mentimun. Seed treatment dengan bakteri yang diisolasi dari perakaran tanaman atau formulasinya mampu meningkatkan ketahanan terhadap serangan patogen pada beberapa jenis tanaman (Kishore et al., 2005).

Namun demikian bakteri endofit juga telah diketahui mempunyai kemampuan sebagai penginduksi ketahanan sistemik. Bakteri Serratia plymuthica yang diaplikasikan pada biji mentimun terbukti mampu meningkatkan ketahanan tanaman tersebut terhadap serangan Pythium ultimum dengan memicu terbentuknya perlindungan fisik dan akumulasi fitoaleksin (Benhamou et al., 2000). Demikian juga beberapa bakteri yang diisolasi dari daerah filoplen yang diaplikasikan sebagai seed treatment mampu memicu pertumbuhan kacang tanah dan meningkatkan produksi hasil disamping meningkatkan ketahanan tanaman terhadap serangan penyakit (Kishore et al., 2005).

\section{BAHAN DAN METODE}

Tanaman $M$. pruriens ditanam di Ciparanje, Jatinangor untuk dipanen biji dan daunnya. Percobaan dilaksanakan di Laboratorium Fitopatologi dan Rumah Kaca Jurusan Hama dan Penyakit Tumbuhan Fakultas Pertanian Universitas Padjadjaran, Jatinangor, pada ketingiaan \pm 700 meter di atas permukaan laut. Percobaan dilakukan dari bulan Juli sampai November 2007.

Isolasi Jamur Cercospora sp.

Sampel tanaman bergejala diperoleh dari tanaman kacang tanah di daerah Tanjungsari, Sumedang. Daun kacang tanah di lapangan yang menunjukkan gejala dimasukkan ke dalam kantong plastik. Di laboratorium, daun tersebut dipotong dengan antara bagian yang sehat dan sakit (Agrios, 1997). Kemudian potongan daun diletakkan pada media Potato Dextrose Agar (PDA). Selanjutnya jamur yang tumbuh diisolasi dan isolat jamur Cercospora sp. dimurnikan. Selama percobaan, jamur ini ridak menghasilkan konidia.

\section{Isolasi Bakteri Inhabitan Mucuna}

Isolasi bakteri dari permukaan daun dilakukan melalui pencucian berseri (Shipton et al., 1981) yang dilakukan dua sampai 10 kali pencucian. Caranya, daun dipotong kecil-kecil dan hasil potongan tersebut dimasukkan ke dalam botol 
Universal yang berisi $10 \mathrm{ml}$ air steril yang mengandung Tween 80 (2 $\mathrm{ml}^{1^{-1}}$ akuades steril), kemudian botol dikocok menggunakan shaker selama 2 menit untuk pencucian yang pertama kali. Selanjutnya dilakukan pencucian dengan menggunakan $10 \mathrm{ml}$ akuades steril. Sebanyak 0,25 ml air pencucian kemudian diteteskan pada mcdia Nutrient Agar (NA) dan diinkubasikan selama 48 jam pada suhu $25^{\circ} \mathrm{C}$.

Bakteri endofit diisolasi dengan menggunakan metode yang dilakukan oleh Coombs \& Franco (2003) yaitu daun dicuci dengan air mengalir untuk menghilangkan kotoran atau mikrob yang mungkin terdapat pada permukaan daun. Setelah itu daun dicuci dalam 99\% etanol selama 60 detik, kemudian dicuci lanjut dalam 3,125\% $\mathrm{NaOCl}$ selama 6 menit lalu dilanjutkan kembali dalam 99\% etanol selama 30 detik dan terakhir dicuci dengan air steril. Tahap selanjutnya daun tersebut dikeringudarakan, kemudian ditumbuk dengan menggunakan mortal dan pestle. Hasil tumbukan daun diletakkan di atas media NA dalam petridish dan diinkubasikan selama 48 jam pada temperatur $25^{\circ} \mathrm{C}$. Bakteri (filoplane dan endofit) hasil isolasi diperbanyak pada media NA.

Untuk uji potensi PGPB, benih kacang tanah disterilkan permukaannya dengan merendamnya di dalam larutan kloroks 1\% selama satu menit kemudian dikeringanginkan. Bakteri dibuat suspensinya $\left(10^{6} \mathrm{CFU}_{\mathrm{ml}}^{-1}\right)$ dan benih kemudian direndam di dalam suspensi bakteri tersebut yang ditambahkan Tween 80 (2 $\left.\mathrm{ml}^{-\mathrm{l}^{-1}}\right)$ sebagai perekat (Coombs et al., 2003). Benih kemudian ditumbuhkan pada pot-pot plastik.

Perbanyakan dan Pembuatan Suspensi Bakteri

Bakteri disuspensikan ke dalam air, kemudian $100 \mu \mathrm{l}$ suspensi diteteskan ke dalam media NA pada petridish dan diratakan dengan menggunakan gelas L. Untuk keperluan inokulasi benih, suspensi bakteri dibuat dengan cara menambahkan $10 \mathrm{ml}$ air ke dalam satu petridish biakan murni bakteri, kemudian biakan murni bakteri dikikis dengan menggunakan gelas $\mathrm{L}$ untuk memisahkan bakteri dari media NA. Suspensi yang sudah tercampur dituangkan ke dalam tabung reaksi, lalu dihomogenkan dengan shaker selama tiga menit.

\section{Penyediaan Media Tanam}

Tanah yang digunakan adalah tanah yang berasal dari kebun percobaan Fakultas Pertanian, Unpad, Jatinangor. Tanah dan pupuk kandang dipasteurisasi dengan cara mengukus selama 5 jam pada suhu sekitar $80^{\circ} \mathrm{C}$. Tanah kemudian dicampur dengan pupuk kandang yang telah dipasteurisasi dengan perbandingan 3:1.

\section{Uji Efikasi Ekstrak Biji Mucuna terhadap Jamur} Cercospora sp.

Ekstrak tanaman disiapkan dengan cara memblender $50 \mathrm{~g}$ biji atau daun dalam $100 \mathrm{ml}$ akuades steril selama 10 menit. Ekstrak etanol disiapkan dengan cara yang sama dengan menggunakan etanol 50\%. Maserasi disaring dengan menggunakan empat lapis kain muslin, kertas saring Whatman No.1, dan kemudian untuk ekstrak air disterilkan dengan menggunakan saringan millipore (ukuran 0,2 $\mathrm{\mu m}$ ). Ekstrak yang dihasilkan disimpan dalam botol-botol secara aseptik pada suhu rendah. sampai digunakan. Pengujian efikasi ekstrak dilakukan terhadap penckanan pertumbuhan patogen. Ekstrak dicampurkan (1:10) pada Petri dish steril dengan media PDA (4\%, double concentration) hingga bercampur merata. Patogen yang diuji berupa biakan murni pada media PDA dipotong dengan cork borer berdiameter $0,5 \mathrm{~cm}$ kemudian diletakkan di tengah Petri dish. Pertumbuhan patogen (diameter koloni jamur) diamati pada interval waktu. 24 jam (Dhingra \& Sinclair, 1985).

Uji Potensi Bakteri Inhabitan terhadap Penekanan Penyakit Bercak Daun Cercospora

Seleksi potensi bakteri yang memacu pertumbuhan tanaman dilakukan dengan cara mengukur tinggi tanaman. Pengukuran dilakukan setelah tanaman kacang tanah berumur 2 minggu setelah tanam. Isolat yang menyebabkan pertumbuhan tanaman lebih tinggi dari tanaman perlakuan kontrol dipilih dan tanamannya dipindahtanamkan ke dalam polibag ukuran $2 \mathrm{~kg}$ dengan media tanah dan pupuk pasteurisasi. Tanaman hasil seleksi tersebut lebih lanjut diuji dalam pengujian penekanan penyakit bercak daun cercospora.

Tanaman kacang tanah diinokulasi jamur Cercospora sp. pada 3 minggu setelah pindah tanam dengan suspensi miselium sampai nun off (sekitar 10 $\mathrm{ml}$ per tanaman). Pada saat inokulasi dan beberapa hari setelah inokulasi tanaman kacang tanah disungkup dengan tutup plastik, dengan tujuan untuk menjaga kelembapan. Suspensi miselium diinokulasikan dengan cara disemprotkan dan dioleskan pada daun tanaman kacang tanah. 


\section{Pengamatan Intensitas penyakit}

Pengamatan intensitas penyakit dimulai setelah munculnya gejala. Variabel yang diamati adalah kenampakan gejala bercak dan persentase serangan Cercospora sp. setelah inokulasi. Pengamatan terhadap gejala bercak Cercospora sp. dilakukan setiap 7 hari dan evaluasi persentase serangan pada tanaman kacang tanah dilakukan setelah 4 kali pengamatan. Penghitungan intensitas penyakit dilakukan berdasarkan rumus:

$$
I=\frac{\sum \text { (n.v) }}{\text { N.V }} \text { x 100\% }
$$

\section{Keterangan :}

$\mathrm{I}=$ Intensitas penyakit (\%)

$\mathbf{n}=$ Jumlah daun yang mempunyai nilai skor tertentu $\mathrm{v}=$ Nilai skor penyakit

$\mathrm{N}=$ Jumlah total daun yang diamati

$\mathrm{V}=$ Nilai skor penyakit tertinggi yang digunakan

Skor yang digunakan dalam penghitungan intensitas penyakit adalah modifikasi dari rumus Horsfall Barratt (1945) dalam Edema et al. (1997) yaitu:

0 = tidak ada serangan

$1=0-25 \%$ bagian tanaman tersinfeksi

$2=>25-50 \%$ bagian tanaman tersinfeksi

$3=>50 \%$ bagian tanaman tersinfeksi

\section{Penghitungan Penekanan penyakit}

Persentase penekanan penyakit dihitung setelah mendapat jumlah rata-rata intensitas penyakit pada setiap perlakuan. Penghitungan dilakukan untuk mengetahui besar kecilnya persentase kemampuan isolat bakteri dalam menekan penyakit bercak daun. Jumlah rata-rata intensitas penyakit tiap perlakuan dibandingkan dengan jumlah rata-rata intensitas penyakit pada kontrol berdasarkan rumus:

$$
\mathrm{P}=\frac{\text { IKontrol }- \text { IPerlakuan }}{\text { IKontrol }}
$$

Keterangan:

$\mathrm{P}=$ Penekanan penyakit (\%)

$\mathrm{I}$ = Rata-rata intensitas serangan penyakit (\%)

\section{HASIL DAN PEMBAHASAN}

\section{Uji Efikasi Ekstrak Biji dan Daun Mucuna terhadap} Cercospora sp.

Hasil pengujian menunjukkan bahwa bahan tanaman yang diekstrak dengan menggunakan etanol memperlihatkan daya hambat pertumbuhan jamur yang lebih tinggi dibandingkan dengan bahan tanaman yang diekstrak dengan menggunakan air. Penekanan perkembangan patogen terbaik ditunjukkan oleh ekstrak etanol biji Mucuna aksesi NTT dengan penekanan perkembangan patogen sebesar 40,38\% dan ekstrak etanol daun aksesi NTT sebesar $35,26 \%$. Penekanan perkembangan patogen (diukur dari diameter pertumbuhan koloni jamur) untuk esktrak yang lainnya (ekstrak air ataupun etanol biji dan daun aksesi NTT dan Jabar) berkisar antara $1,28 \%-33,97 \%$.

Ekstrak yang dihasilkan dari ekstraksi etanol ini juga cairannya lebih pekat, menghasilkan minyak yang lebih banyak, dan aroma yang lebih. kuat dibandingkan dengan ekstrak air. Etanol merupakan solvent yang paling efisien yang biasa digunakan untuk pengekstaksian bahan aktif dari bahan-bahan tanaman. Namun demikian, tampaknya kemampuan masing-masing ekstrak dalam menekan pertumbuhan jamur juga ditentukan oleh jenis aksesi Mucuna itu sendiri. Aksesi yang berasal dari NTT ditengarai mempunyai kemampuan menekan lebih baik dibandingkan dengan aksesiaksesi Mucuna yang berasal dari Jabar.

Uji Potensi Peningkatan Pertumbuhan Tanaman oleh Bakteri Inhabitan Mucuna

Isolasi bakteri inhabitan Mucuna yang diperkirakan merupakan bakteri endofit maupun filoplen menghasilkan 17 isolat bakteri dengan rincian 11 isolat bakteri endofit (Kode Isolat ME: ME1-ME7=Jabar; ME16-ME19 = NTT), dan 6 isolat bakteri filoplen (Kode Isolat MF: MF1-5 = Jabar; MF13 = NTT). Karakteristik isolat bakteri disajikan pada Tabel 1.

Semua isolat bakteri inhabitan $M$. pruriens memiliki warna koloni coklat mengkilap dengan bentuk koloni sebagian besar tidak rata dan bebrapa koloni berupa benang. Permukaan koloni hampir semua datar dan tepi koloni bervariasi yaitu rata, berombak, bergelombang, ataupun berupa benang. Menurut Tan et al. (1999) bakteri-bakteri endofit yang diisolasi dari tanaman legum-leguman umumnya merupakan gram negatif, anaerob 
fakultatif, serta koloninya berwarna coklat atau bening.

Tabel 1. Karakteristik isolat bakteri inhabitan $M$. Pruriens.

\begin{tabular}{lllll}
\hline $\begin{array}{c}\text { Kode } \\
\text { Isolat }\end{array}$ & Coklat & $\begin{array}{c}\text { Bentuk } \\
\text { koloni }\end{array}$ & $\begin{array}{c}\text { Permukaan } \\
\text { koloni }\end{array}$ & $\begin{array}{l}\text { Tepi } \\
\text { koloni }\end{array}$ \\
\hline ME1 & Coklat & Irregular & Flat & Labate \\
ME2 & Coklat & Irregular & Flat & Lobate \\
ME3 & Coklat & Irregular & Flat & Lobate \\
ME4 & Coklat & Irregular & Flat & Lobate \\
ME5 & Coklat & Filamentous & Flat & Filiform \\
ME6 & Coklat & Filamentous & Flat & Filiform \\
ME7 & Coklat & Circular & Flat & Entire \\
ME16 & Coklat & Circular & Flat & Eritire \\
ME17 & Coklat & Filamentous & Flat & Filiform \\
ME18 & Coklat & Irregular & Flat & Undulate \\
ME19 & Coklat & Irregular & Flat & Lobate \\
MF1 & Coklat & Irregular & Flat & Lobate \\
MF2 & Coklat & Irregular & Grateriform & Lobate \\
MF3 & Coklat & Irregular & Flat & Undulate \\
MF4 & Coklat & Irregular & Raised & Entire \\
MF5 & Coklat & Irregular & Flat & Entire \\
MF13 & Coklat & Circular & Convex & Entire \\
\hline
\end{tabular}

Keterangan: Karakteristik bakteri menurut Johnston (2007) dan Salle (1961).

Pada pengujian potensi bakteri inhabitan dalam meningkatkan pertumbuhan tanaman diperoleh beberapa isolat bakteri yang cenderung meningkatkan pertumbuhan tanaman kacang tanah. Tanaman yang tumbuh dari benih yang diberi perlakuan bakteri ini menunjukkan pertumbuhan tanaman yang lebih tinggi dibandingkan dengan perlakuan kontrol walaupun tidak mampu meningkatkan pertumbuhan tanaman kacang tanah secara nyata (Tabel 2). Isolat tersebut adalah ME2, ME3, ME4, ME7, ME16, dan MF 3.

Kemampuan bakteri endofit untuk meningkatkan pertumbuhan tanaman inang telah banyak dilaporkan (Hallmann et al., 1997). Bakteri endofit yang dilaporkan memiliki kemampuan untuk meningkatkan pertumbuhan tanaman ini diisolasi dari semua bagian tumbuhan seperti daun, batang, dan akar yang karena dapat meningkatkan pertumbuhan tanaman maka meningkatkan juga berat kering, berat basah, maupun ukuran dan jumlah daun (Nejad \& Jhonson, 2000).

Menurut Ramamoorthy et al. (2001) bakteri endofit dapat dijadikan sebagai agens pemacu pertumbuhan, bakteri endofit berasosiasi dengan jaringan internal tanaman dengan mengadakan suatu rangsangan pertumbuhan yang relatif sama seperti PGPR. Bakteri mengolonisasi jaringan internal dan bergerak ke seluruh bagian tanaman dari titik penetrasi. Van Vuurde \& Recuenco (2005) melaporkan bahwa kemampuan bakteri endofit dalam memacu pertumbuhan tanaman pada awal pertumbuhan tanaman dengan cara menginduksi produksi auksin serta membantu tanaman untuk mengatasi infeksi patogen. Begitupun kemampuan bakteri filoplen dalam meningkatkan pertumbuhan tanaman inang telah banyak dilaporkan (Beattie \& Lindow, 1999; Kishore et al., 2005; Wilson et al., 1999).

Tabel 2. Pengaruh bakteri inhabitan $M$. pruriens terhadap tinggi tanaman kacang tanah pada umur 2 minggu setelah tanam.

\begin{tabular}{|c|c|c|}
\hline \multirow{2}{*}{$\begin{array}{r}\text { Isolat bakteri } \\
\text { ME } 1\end{array}$} & \multicolumn{2}{|c|}{ Tinggi tanaman $(\mathrm{cm})$} \\
\hline & 4,33 & $\mathrm{ab}$ \\
\hline ME 2 & 10,50 & cde \\
\hline ME 3 & 10,93 & de \\
\hline ME 4 & 10,67 & cde \\
\hline ME 5 & 5,50 & abcd \\
\hline ME 6 & 4,50 & $a b$ \\
\hline ME 7 & 11,00 & de \\
\hline ME 16 & 12,67 & $\mathrm{e}$ \\
\hline ME 17 & 8,50 & bcde \\
\hline ME 18 & 3,50 & $\mathrm{ab}$ \\
\hline ME 19 & 7,10 & bcde \\
\hline MF 1 & 5,50 & abcd \\
\hline MF 2 & 0,60 & a \\
\hline MF 3 & 10,67 & cde \\
\hline MF 4 & 4,16 & $a b$. \\
\hline MF 5 & 0,67 & a $\cdots$ \\
\hline MF 13 & 5,00 & abc \\
\hline Kontrol & 8,50 & bcdè \\
\hline
\end{tabular}

Keterangan: Nilai rata-rata yang diikuti oleh huruf yang sama pada kolom yang sama tidak berbeda nyata menurut Uji Jarak Berganda Duncan pada taraf nyata 5\%.

Beberapa isolat bakteri menghambat pertumbuhan tanaman, dimana pertumbuhan tanaman dengan perlakuan isolat bakteri jauh lebih kecil daripada perlakuan kontrol (tanpa suspensi bakteri). Menurut Van Vuurde \& Recuenco (2005) umumnya bakteri endofit yang ada pada tanaman budidaya bersifat netral terhadap pertumbuhan tanaman, namun diperkirakan sekitar 20\% dapat 
menghambat pertumbuhan tanaman dan hanya sekitar $10 \%$ saja yang mampu memacu pertumbuhan tanaman. Hallmann (1999) melaporkan juga bahwa hanya sepertiga dari seluruh kelompok bakteri endofit yang mampu mendukung pertumbuhan dan kesehatan tanaman. Begitupun isolat bakteri filoplen tidak seluruhnya berpotensi untuk hal tersebut (Beattie \& Lindow, 1999; Viera et al., 2006; Wilson et al., 1999).

Uji Potensi Bakteri Inhabitan Mucuna Terhadap Penekanan Penyakit Bercak Daun (Cercospora sp.) pada Tanaman Kacang Tanah

Tanaman kacang tanah yang cenderung lebih tinggi dari perlakuan kontrol dipindahtanamkan ke dalam polibag, kemudian diinokulasi dengan suspensi miselium jamur Cercospora sp. pada saat 3 minggu setelah pindah tanam. Pengamatan dan penghitungan intensitas penyakit dilakukan setiap minggu dari pengamatan minggu pertama inokulasi sampai minggu ke empat. Gejala (bercak daun berwarna coklat) pertama kali (pengamatan minggu pertama) muncul pada perlakuan kontrol dan perlakuan isolat MF3.

Perlakuan benih dengan isolat bakteri ini menunjukkan intensitas penyakit yang lebih rendah daripada perlakuan kontrol pada semua perlakuan isolat bakteri (Tabel 3). Walaupun demikian hanya satu perlakuan isolat bakteri yaitu perlakuan ME3 yang secara statistik memiliki persentase intensitas penyakit yang berbeda nyata dengan perlakuan kontrol dengan penekanan penyakit tertinggi yaitu $70,85 \%$.

Intensitas penyakit bercak daun pada perlakuan kontrol sebesar 9,71\% dan intensitas tertinggi setelah kontrol ditunjukkan oleh isolat MF3 (8,59\%). Seperti pada pengujian potensi peningkatan pertumbuhan tanaman, bakteri endofit menunjukkan kemampuan yang lebih superior dibandingkan dengan kemampuan bakteri filoplen dalam menekan penyakit bercak daun cercospora.

Secara keseluruhan selama percobaan, intensitas penyakit bercak daun relatif kecil. Terdapat beberapa kemungkinan yang dapat menjadi penyebab rendahnya intensitas penyakit bercak daun cercospora tersebut. Pertama, kurang mendukungnya temperatur dan kelembapan rumah kaca selama pengujian dan pertumbuhan tanaman. Kedua, keadaan musim hujan selama percobaan diduga tidak mendukung tersedia inokulum yang tersedia secara alami di sekitar pertanaman. Menurut Pretorius (1996) kondisi musim panas sangat mendukung pembentukan konidia Cercospora dan perkembangan penyakit, sementara penelitian dilakukan pada musim hujan (di Indonesia tanaman kacang tanah $70 \%$ ditanam pada saat musim hujan untuk menghindari penyakit ini). Kemungkinan lain yaitu varietas lokal kacang tanah yang digunakan dalam penelitian diduga cukup toleran terhadap serangan Cercospora.

Tabel 3. Intensitas penyakit bercak daun cercospora pada tanaman kacang tanah pada perlakuan isolat bakteri inhabitan Mucuna pada 4 minggu setelah inokulasi.

\begin{tabular}{cccc}
\hline Kode Isolat & $\begin{array}{c}\text { Intensitas } \\
\text { Penyakit (\%) }\end{array}$ & $\begin{array}{c}\text { Penekạnan } \\
\text { Penyakit (\%) }\end{array}$ \\
\hline ME2 & 4,22 & ab & 56,54 \\
ME3 & 2,83 & b & 70,85 \\
ME4 & 4,75 & ab & 51,08 \\
ME7 & 6,81 & ab & 29,87 \\
ME16 & 6,70 & ab & 31,00 \\
MF3 & 8,59 & ab & 11,53 \\
Kontrol & 9,71 & a & $0^{\circ}$ \\
\hline
\end{tabular}

Keterangan: Nilai rata-rata yang diikuti oleh huruf yang sama pada kolom yang sama tidak berbeda nyata menurut Uji Jarak. Berganda Duncan pada taraf nyata 5\%.

Penekanan penyakit yang terjadi pada penelitian ini diduga karena perlakuan beriih kacang tanah dengan isolat bakteri dapat menginduksi ketahanan tanaman kacang tanah dimana isolat bakteri berperan sebagai penginduksi ketahanan. Menurut Desmawati (2006), perlakuan benih atau prainokulasi dengan agens penginduksi dapat mengaktifkan secara cepat peningkatan mekanisme akumulasi fitoaleksin yang mampu menginduksi ketahanan pada tanaman. Senyawa fitoaleksin adalah substansi antibiotik yang diproduksi oleh tanaman inang apabila ada infeksi patogen. Jadi pada prinsipnya ketahanan tanaman dapat dipicu oleh agens stimulan sebelum terjadi infeksi oleh patogen. dan intensitas penyakit dapat menurun. Ditegaskan Van Vuurde \& Recuenco (2005) dan Viera et al. (2006) bahwa secara umum keberadaan bakteri inhabitan tumbuhan yang memiliki kemampuan menekan penyakit tanaman, terjadi melalui mekanisme induksi ketahanan sistemik. 


\section{SIMPULAN DAN SARAN}

\section{Simpulan}

Hasil percobaan uji efikasi ekstrak biji dan daun Mucuna terhadap Cercospora sp. menunjukkan hasil tanaman yang diekstraksi dengan etanol memberikan hasil lebih baik daripada ekstrak air. Hasil terbaik ditunjukkan oleh ekstrak etanol biji Mucuna asal NTT dengan penekanan pertumbuhan patogen sebesar $40,38 \%$. Terdapat beberapa bakteri inhabitan $M$. pruriens yang cenderung meningkatkan pertumbuhan tanaman kacang tanah serta terdapat isolat bakteri yang dapat menekan penyakit bercak daun cercospora dengan penekanan tertinggi sebesar 70,85\% yang ditunjukkan oleh isolat ME 3 yang diisolasi dari daun Mucuna asal Jawa Barat.

Saran

Pengujian PGPB dapat dilakukan dengan cara perlakuan benih. Pengujian bakteri PGPB dan ekstrak Mucuna perlu dilakukan pada tanaman kacang-kacangan jenis lain.

\section{UCAPAN TERIMAKASIH}

Penelitian ini merupakan sebagian dari penelitian yang didanai oleh Program Hibah Kompetensi A3, Jurusan Hama dan Penyakit Tumbuhan, Fakultas Pertanian, Universitas Padjadjaran.

\section{DAFTAR PUSTAKA}

Agrios, GN. 1997. Plant Pathology. $3^{\text {rd }}$ Edition. Academic Press. San Diego. 635 p.

Arora, NK, SC Kang, and DK Maheswari. 2001. Rhizobium meliloti and their biocontrol potential against Macrophomina phaseolina that causes charcoal rot of groundnut. Current Science. 81(6): 673-677.

Beattie, GA and SE Lindow. 1999. Bacterial colonization of leaves: a spectrum of strategies. Phytopathology. 89(5): 353-359.

Benhamou, N, S Gagane, D Lequere, and L Dehbi. 2000. Bacterial-mediated induced resistance in cucumber: Beneficial effect of the endophytic bacterium Serratia plymuthica on the protection against infection by Phytium ultimum. Phytopathology. 90: 4556.
Chandra, S, S Kumar, and AK Singh. 1998. Management of cercospora leaf spot of groundnut (Arachis hypogaea L.) with a single fungicidal spray. International Journal of Pest Management. 44 (3): 135137.

Compant, S, B Duffy, J Nowak, C Clement, and AA Barka. 2005. Use of plant growth-promoting bacteria for biocontrol of plant disease: Principle, mechanisms of action, and future prospect. Applied and Environmental Microbiology. 71 (9): 4951-4959.

Coombs, JT and CMM Franco. 2003. Isolation and identification of actinobacteria from surface-sterilized wheat roots. Applied and. Environmental Microbiology. 69(9): 56035608.

Cu, RM and PM Phipps. 1993. Development of a pathogen growth response model for the peanut leaf spot advisory "program. Phytopathology. 83(2): 127-252.

Culbreath, AK, KL Stevenson, and TB Brenneman. 2002. Management of late leaf spot of peanut with Benomyl and Chlorothalonil: A study in preserving fungicide uitility. Plant Disease. 86(4): 349-355.

Desmawati. 2006. Pemanfaatan Plant. Growth Promoting Rhizobacter (PGPR) Prospek yang Menjanjikan dalam Berusaha Tani Tanaman Hortikultura. POPT Direktorat Perlindungan Tanaman Hortikultura. Ditjen Hortikultura. Nganjuk. Tersedia online pada. http://ditlin.hortikultura.go.id (diakses 3 April 2008).

Dhingra, OD and JB Sinclair. 1985. Basic Plant Pathology Methods. CRC Press Inc. Florida.

Dwivedi, SL, S Pande, JN Rao, and SN Nigam. 2002. Component of resistance to late leaf spot and rust among interspecific derivatives and their significance in a foliar disease resistance breeding in groundnut (Arachis. hypogaea. L). Biomedial and Life Science. 125(1): 81-88.

Edema, R, E Adipala, and DA Florini. 1997. Influence of season and cropping system on occurrence of cowpea disease in Uganda. Plant Disease. 81: 465-468.

Grichar, WJ, BA Besler, and AJ Jack. 1998. Peanut (Arachis hypogea L.) cultivar response to leaf spot disease development under. four disease management program. Peanut Sci. 25: 35-39. 
Hallmann, J. 1999. Plant Interactions with Endophytic Bacteria. Biotic Interactions in Plant-Pathogen Associations. Bonn University Germany. Available on line at: www.bspp.org.uk/archives (diakses 13 Juni 2007).

Johnston, D. 2007. Colony Characteristics. Available on line at: http:// faculty.clinton.edu/faculty.html. (diakses 19 Maret 2008).

Kishore, GK, S Pande, and AR Podile, 2005. Phylloplane bacteria increase seedling emergence, growth and yield of field-grown groundnut (Arachis hypogaea L.). Letters in Applied Microbiology. 40: 260-268.

Kloepper, JW, R Ubana, GW Zehnder, JF Murphy, E Sikora, and C Fernandez. 1999. Plant rootbacterial interactions in biological control of soilborne disease and potential extension to systemic and foliar disease. Australian Plant Pathology. 28: 21-26.

Kumar, B, MS Kumar, K Annapurna, and DK Maheswari. 2006. Genetic diversity of Plant Growth-Promoting Rhizobia isolated from a medicinal legume, Mucuna pruriens Linn. Current Science. 91(11):1524-1529.

Lindow, SE and MT Brandl. 2003. Microbiology of the Phyllosphere. Applied and Envirönmental Microbiology. 69(4): 18751883.

Nejad, P and PA Jhonson. 2000. Endophytic bacteria induce growth promotion and wilt disease suppression in oilseed rape and tomato. Biological Control Journal. 18: 208-215.

Nindiawaty, S, AIR Sastrahidayat, dan AL Abadi. 2005. Pemanfaatan mikroorganisme antagonis dari filosfer dan rhizosfer untuk menekan serangan penyakit bercak daun (Cercospora Personata Berk \& Curt) pada tanaman kacang tanah (Arachys hypogaea L).Fakultas Pertanian Universitas Brawijaya. Jurnal Ilmiah Habitat. XVI (3): 202 - 215.

Rajeshwar, Y, M Gupta, and UK Mazumder. 2005. In vitro lipid peroxidation and antimicrobial activity of Mucuna pruriens seeds. Iranian Journal of Pharmacology and Therapeutics. 4: 32-35.

Ramamoorthy, V, R Viswanathan, T Raguchander, V Prakasam, and R Samiyappan. 2001. Induction of systemic resistance by Plant Growth Promoting Rhizobacteria in crop plant against pest and disease. Crop Protection. 20: 1-11.

Reiter, B, U Pfeifer, H Schwab, and A Sessitsch. 2002. Response of endophytic bacterial communities in potato plants to infection with Erwinia carotovora subsp. Atroseptica. Applied and Environmental Microbiology. 68 (5): 2261-2268.

Pensuk, V, A Patanothai, S Jogloy, S Wongkaew, C Akkasaeng, and N Vorasoot. 2003. Reaction of peanut cultivars to late leafspot and rust. Songklanakarin J. Sci. Technol. 25(3): 289295.

Pretorius, AE. 2006. Evaluation of Groundnut (Arachis hypogaea L.) Germplasm for Resistance to Leaf Disease and Related. Cytoplasmic Factors, Testa Colour and Cup Leaf. Thesis Department of Plant "Science Faculty of Natural and Agricultural Science University of The Free State. Bloemfontein. South Africa. Available on line at: www.etd.uovs.ac.za (diakses 13 Juni 2007),

Salle, AJ. 1961. Fundamental Principles of Bacteriology, McGraw-Hill Book Company Inc. New York. 812 p.

Sathiyanarayanan, L and S Arulmozhi. 2007. Mucuma pruriens Linn. A Comprehensive Review. Phcog. Rev. 1(1): 157-162.

Semangun, H. 1993. Penyakit-Penyakit Tanaman Pangan di Indonesia. Gadjah' Mada University Press. HIm 117-120.

Shipton, WA, RL Mc Cown, and WT Williams. 1981. Influence of weather on mouldiness and the mycoflora of legume pasture during the dry season in tropical Australia. Australian Journal of Borany. 29: 59-69.

Tan, ZY, ET Wang, GX Peng, ME Zhu, E MartinezRomero, and WX Chen. 1999. Characterization of bacteria isolated from wild legumes in the North-western of China. International Journal of Systemic Bacteriology. 49: 1457-1469.

Utomo, SD, E Setiowati, dan HM Akin. 2005. Ketahanan terhadap penyakit bercak daun lambat (Cercosporidium personatum) dan karakter ggronomi kacang tanah famili F5 keturunan persilangan Kelinci $\mathbf{x}$ Southern Runner. Jurnal Hama dan Penyakit Tumbuhan Tropika. 5(2): 104-112.

Van Vuurde, JWL and ME Recuento. 2005. Endophyte Management as Tool Optimize Plant Quality. Available on . line at: 
http://www.ag.auburn.edu (diakses 5 Januari 2008).

Vieira, BAH, JRV Júnior, RS Romeiro, HSA Silva, and MCB Pereira. 2006. Induction of systemic resistance in tomato by the autochthonous phylloplane resident Bacillus cereus. Phytopathology Brasilia. Vol. 41 No.8. Available on line at: http://www.scielo.br/scielo (diakses 13 April 2008).

Wei, G, JW Kloepper, and S Tujun. 1991. Induction of systemic resistance cucumber to Colletotrichum orbiculare by selected strains of Plant Growth-Promoting Rhizobacteria. Phytopathology. 81(12): 1508-1512.

Wilson, M, SS Hirano, and SE Lindow. 1999. Location and survival of leaf-associated bacteria in relation to pathogenicity and potential for growth within the leaf. Applied and Environmental Microbiology. 65 (4): 1435-1443.
Zasada, IA Klassen, W Meyer, SLF Codallo, M Abdul-Baki, and A Aref. 2006. Velvet bean (Mucuna pruriens) extracts: Impact on Melodygne incognita survival and on Lycopersicon esculentum and Lactuca sativa germination and growth. Pest Management Science. 62(11): 1122-1127.

Zhang, S and MS Reddy. 2001. Lack of Induced Systemic Resistance in peanut to late leaf spot disease by Plant Growth-Promoting Rhizobacteria and chemical elicitors. Plant Disease. 85(8): 879-884.

Zinniel, DK, P Lambrecht, NB Harris, Z Feng, D Kuczmarski, P Higley, CA Ishimaru; A Arunakumari, RG Barletta, and AK Vidaver. 2002. Isolation and characterization of endophytic colonizing bacteria from agronomic crops and prairie plants. Applied and Environmental Microbiology. 68 (5): 2198 - 2208. 